AL IBTIDA: JURNAL PENDIDIKAN GURU MI (2018) Vol 5 (1) : 133-144

DOI: http://dx.doi.org/ 10.24235/al.ibtida.snj.v5i1.2505

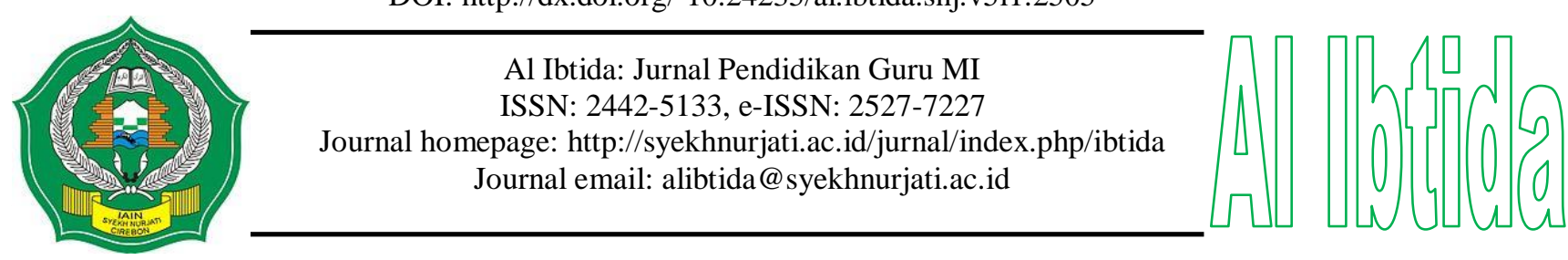

\title{
Pengaruh Penerapan Gaya Belajar Terhadap Kemampuan Membaca Intensif pada Pelajaran Bahasa Indonesia Siswa SD Negeri Sunyaragi 1 Kota Cirebon
}

\author{
Patimah* \\ *Program Studi Pendidikan Guru Madrasah Ibtidaiyah, Fakultas Ilmu Tarbiyah dan Keguruan, \\ IAIN Syekh Nurjati Cirebon \\ Email: patimahwardono@gmail.com \\ Faisal Abdullah** \\ **Program Studi Pendidikan Guru Madrasah Ibtidaiyah, Fakultas Ilmu Tarbiyah dan Keguruan, \\ IAIN Syekh Nurjati Cirebon \\ Email: icalabdullah8@gmail.com
}

Received 21 February 2018; Received in revised form: 28 June 2018; Accepted 29 June 2018 Publish Online: 30 June 2018

\begin{abstract}
Abstrak
Berdasarkan hasil observasi di kelas V SD Negeri Sunyaragi I diketahui bahwa siswa masih mengalami kesulitan dalam memahami suatu bacaan. Salah satu penyebabnya adalah guru cenderung menggunakan metode ceramah dan belum mengoptimalkan kemampuan gaya belajar siswa yang berbeda-beda, terutama tentang belajar membaca intensif. Penelitian ini bertujuan untuk mengetahui bagaimana respon siswa terhadap penerapan pembelajaran berdasarkan gaya belajar siswa, bagaimana kemampuan membaca intensif pada pelajaran Bahasa Indonesia dan seberapa besar pengaruh pembelajaran berdasarkan gaya belajar terhadap kemampuan membaca intensif pada mata pelajaran Bahasa Indonesia siswa kelas V SD Negeri Sunyaragi 1 Kota Cirebon. Penelitian ini menggunakan metode kuantitatif dengan teknik pengumpulan data berupa angket, tes, dan dokumentasi. Sementara itu, teknik analisis data yang digunakan adalah uji persentase angket dan uji regresi. Hasil penelitian menunjukkan bahwa respon siswa terhadap penerapan pembelajaran berdasarkan gaya belajar adalah sangat baik/kuat yakni sebesar $81 \%$. Adapun rata-rata kemampuan membaca intensif siswa kelas $\mathrm{V}$ sebesar 83,57. Lebih lanjut hasil analisis membuktikan bahwa penerapan pembelajaran berdasarkan gaya belajar berpengaruh signifikan terhadap kemampuan membaca intensif pada mata pelajaran Bahasa Indonesia siswa kelas V di SD Negeri Sunyaragi 1 Kota Cirebon sebesar 52,2\%.
\end{abstract}

Kata kunci: gaya belajar, membaca intensif, bahasa indonesia 


\begin{abstract}
Based on the observations in class V SD Negeri Sunyaragi I it is known that students still have difficulty in understanding a reading. One reason is that teachers tend to use lecture methods and have not optimized the ability of different learning styles of students, especially about intensive reading. This study aims to find out how the response of students to the application of learning based on student learning styles, how intensive reading skills in Indonesian lessons and how much influence of learning based on learning styles to the ability of intensive reading on the subjects of Indonesian class V State Elementary Schools Sunyaragi 1 Cirebon City. This study uses quantitative methods with data collection techniques in the form of questionnaires, tests, and documentation. Meanwhile, the technique of data analysis used is test of questionnaire percentage and regression test. The results showed that students' responses to the application of learning based on learning style is good/strong which is equal to $74 \%$. The average intensive reading ability of grade V students amounted to 83.57 . Further analysis results prove that the application of learning based on learning style significantly influence the ability of intensive reading on Indonesian language subjects in class V State Elementary Schools Sunyaragi 1 Cirebon City of 52.2\%.
\end{abstract}

Keywords: learning style, reading intensive, indonesian

\title{
PENDAHULUAN
}

Setiap manusia memiliki potensi yang berbeda-beda.Oleh sebab itu, diperlukan adanya proses pendidikan. Pendidikan merupakan suatu proses melalui metode-metode tertentu sehingga orang akan memperoleh ilmu pengetahuan, pemahaman, dan cara bertingkah laku yang sesuai dengan kebutuhan, yang berarti seluruh tahapan pengembangan pengetahuan dan perilaku untuk mendapatkan pengalaman dalam hidupnya. Dengan adanya proses pendidikan, maka potensi manusia akan tergali dengan maksimal. Untuk itu diperlukan keharmonisasian dalam komunikasi proses belajar anatara guru dengan siswa. Terutama dalam hal memperhatikan bagaimana siswa mendapatkan pengetahuan dan menjadikannya keterampilan yang berkualitas dan kuantitas sesuai dengan undang-undang dasar berikut:

Undang-Undang RI No. 20 Tahun 2003 Pasal 1 ayat (1) tentang Sistem Pendidikan Nasional mengatakan bahwa Pendidikan adalah sebuah usaha yang terencana untuk suasana dan proses pembelajaran di dalam kelas agar peserta didik mengembangkan potensi dirinya secara mandiri untuk memiliki kekuatan spiritual keagamaan, pengendalian diri, kepribadian, kecerdasan, akhlak mulia, serta keterampilan yang diperlukan dirinya masyarakat, bangsa dan Negara.

Kegiatan belajar mengajar seorang anak merupakan pelaku kegiatan pembelajaran. Inti proses pemebelajaran tidak lain adalah seluruh kegiatan peserta didik dalam mencapai tujuan pembelajaran yang telah ditetapkan.Tujuan pembelajaran tentu saja akan dapat tercapai apabila anak didik berusaha secara aktif untuk mencapainya. Menurut Djamarah (2010:38), Slameto dalam Hamdu dan Agustina (2011: 82) mengatakan bahwa pada hakikatnya belajar adalah 
sebuah perubahan yang terjadi dalam pribadi siswa dikarenakan aktivitas belajar. Meskipun dalam kenyataannya tidak semua perubahan termasuk ke dalam kategori belajar.

Grinder (dalam Karwati, 2014: 189), Bire, dkk. (2014), DePorter dan Hernacki (dalam Halim, 2012:143), Sundayana (2016) menyatakan bahwa gaya belajar merupakan kombinasi bagaimana ia menyerap dan kemudian mengatur serta mengolah informasi. Melengkapi pendapat Grinder mengenai gaya belajar, menurut Nasution (dalam Putri, 2013: 4) gaya belajar atau learning style adalah cara bersikap siswa dalam menggunakan indra perangsang dalam proses belajar. Lebih lanjut dikatakan bahwa gaya belajar adalah cara yang dilakukan oleh siswa secara konsisten dalam menangkap stimulus atau informasi, cara mengingat, berfikir dan memecahkan persoalan. Melihat pentingnya gaya belajar yang dimiliki oleh siswa maka peran guru sangat diperlukan dalam mengidentifikasi setiap gaya belajar siswa untuk tercapainya suatu tujuan pembelajaran yang diinginkan.

Gaya belajar dan kualitas pembelajaran memiliki hubungan erat dan pengaruh terhadap proses pembelajaran dalam rangka mencapai tujuan pembelajaran (Widayanti, 2010). Karena pada dasarnya karakter siswa yang satu berbeda dengan siswa lainnya dan kemampuan tiap anak dalam menguasai serta memahami suatu bahan pelajaran berbeda-beda pula (Dimyati \& Mudjiono, 2002). Untuk itu perlu diterapkan pembelajaran dengan gaya belajar yang sesuai dengan karakter siswa. Tubi'c \& Hamilo glu (2009) mengemukakan bahwa penerapan gaya belajar yang sesuai akan meningkatkan proses pembelajaran, bahkan ditegaskan pula olehnya jika ada kesesuaian antara model pembelajaran dengan gaya belajar maka akan tercipta suasana belajar produktif di dalam kelas. Oleh karenanya seorang guru perlu memahami karkateristik siswa seperti yang disampaikan oleh Dick and Carey (1996) yang menyatakan bahwa seorang guru hendaklah mampu mengenal dan mengetahui karakteristik siswa. Sebab dengan pemahaman yang baik terhadap karakteristik siswa, guru akan dapat menyesuaikan metode pembelajaran yang digunakannya yang tentunya sangat mempengaruhi keberhasilan proses belajar siswa.

Penerapan gaya belajar sangat penting dalam pembelajaran. Dalam penelitian yang telah dilakukan, penerapan gaya belajar mempengaruhi prestasi belajar siswa. Bire,dkk. (2014) telah melakukan penelitian untuk mengetahui pengaruh gaya belajar terhadap prestasi hasil belajar siswa. Hasilnya menunjukkan bahwa gaya belajar baik visual, audio, dan kinestetik mampu meningkatkan prestasi belajar secara signifikan. Dari hasil penelitian juga didapatkan hasil bahwa terdapat perbedaan pengaruh yang signifikan antara gaya belajar visual, audio, dan kinestetik terhadap prestasi belajar siswa. Hal ini diperkuat oleh Hasil penelitian yang dilakukan Fitriyah (2007) yang menunjukkan bahwa identifikasi gaya belajar menunjukkan pengaruh yang signifikan terhadap hasil belajar. 
Penelitian serupa yang dilakukan oleh Kolb (2005) menyatakan bahwa hasil belajar kimia siswa dengan memperhatikan gaya belajar menunjukkan hasil yang lebih tinggi dibandingkan hasil belajar tanpa memperhatikan gaya belajar. Senada dengan penelitian di atas, Hartati (2013) meneliti tentang pengaruh gaya belajar terhadap hasil belajar matematika. Hasilnya menunjukkan bahwa terdapat perbedaan hasil belajar matematika siswa yang memiliki gaya belajar visual, auditorial, dan kinestetik. Hal ini ditunjukkan oleh harga F-hitung sebesar 2,94 dengan probabilitas sig $0,047($ sig $<0,05)$ pada taraf signifikansi $=5 \%$. Berdasarkan hasil penelitian, Hasil belajar matematika siswa yang memiliki gaya belajar visual diperoleh skor terendah 53 dan tertinggi 80, nilai rata-rata/mean 65,45, median sebesar 63, modus sebesar 63, varians sebesar 80,080 dan simpangan baku sebesar 8,947. Sedangkan hasil belajar matematika siswa yang memiliki gaya belajar auditorial diperoleh skor terendah 53 dan tertinggi 80, nilai rata-rata/mean 65,25, median sebesar 63, modus sebesar 60, varians sebesar 70,829 dan simpangan baku sebesar 8,416. Selanjutnya hasil belajar matematika siswa yang memiliki gaya belajar kinestetik diperoleh skor terendah 53 dan tertinggi 80, nilai rata-rata/mean 66,80, median sebesar 65, modus sebesar 60, varians sebesar 68,589 dan simpangan baku sebesar 8,282.

Halim (2012) juga meneliti tentang pengaruh gaya belajar terhadap hasil belajar fisika. Ada pengaruh gaya belajar terhadap hasil belajar fisika siswa pada $a=5 \%$. Siswa yang memiliki kecenderungan gaya belajar auditorial memperoleh hasil belajar fisika lebih tinggi dibandingkan siswa dengan gaya belajar visual dan kinestetik. Amir (2015) mengemukakan bahwa terdapat perbedaan kegiatan dalam langkah berpikir kritis dalam memecahkan permasalahan cerita matematik dari gaya belajar visual. Auditori, dan kinestetik. Perbedaan inilah yang membuat prestasi belajar siswa bisa maksimal. Apabila langkah berpikir siswa disamakan tentu hasil belajar siswa akan tidak maksimal karena tidak sesuai dengan karakter siswa. Oleh karenanya seorang guru harus mampu mengetahui karakter siswanya.

Berdasarkan hasil observasi di kelas V SD Negeri Sunyaragi I Kota Cirebon juga ditemukan bahwa siswa masih mengalami kesulitan dalam memahami suatu bacaan. Permasalahan ini timbul salah satunya karena guru cenderung menggunakan metode ceramah dan belum mengoptimalkan kemampuan gaya belajar siswa yang berbeda-beda terutama tentang belajar membaca intensif yang memfokuskan pada pemahaman yang mengaitkan kesulitan siswa dalam memperoleh makna atau informasi dari bacaan yang kompleks. Selain itu, belum optimalnya penerapan keterampilan pedagogik guru dalam memahami gaya belajar siswa dalam menyampaikan materi bahasa indonesia yang sesuai dengan gaya belajar siswa. Hal tersebut berdampak pada penerapan gaya belajar siswa yang keliru dan mengakibatkan kurang tercapainya tujuan pembelajaran yang telah direncanakan. 
Penelitian ini bertujuan untuk mengetahui bagaimana respon siswa terhadap penerapan pembelajaran berdasarkan gaya belajar siswa, bagaimana kemampuan membaca intensif pada pelajaran Bahasa Indonesia dan seberapa besar pengaruh pembelajaran berdasarkan gaya belajar terhadap kemampuan membaca intensif pada mata pelajaran Bahasa Indonesia siswa kelas V SD Negeri Sunyaragi 1 Kota Cirebon.

\section{METODE PENELITIAN}

Penelitian ini menggunakan metode kuantitatif deskriptif. Metode kuantitafi deskriptif ini menurut Hasan (2002: 33) bertujuan untuk menguraikan sifat atau karakteristik dari suatu fenomena tertentu. Pengumpulan data menggunakan intrumen penelitian, analisis data bersifat kuantitatif atau statistik dengan tujuan untuk menguji hipotesis yang telah ditetapkan dengan desain deskriptif. Adapun diagram desain penelitian ini adalah sebagai berikut:

Gambar 1. Desain Penelitian

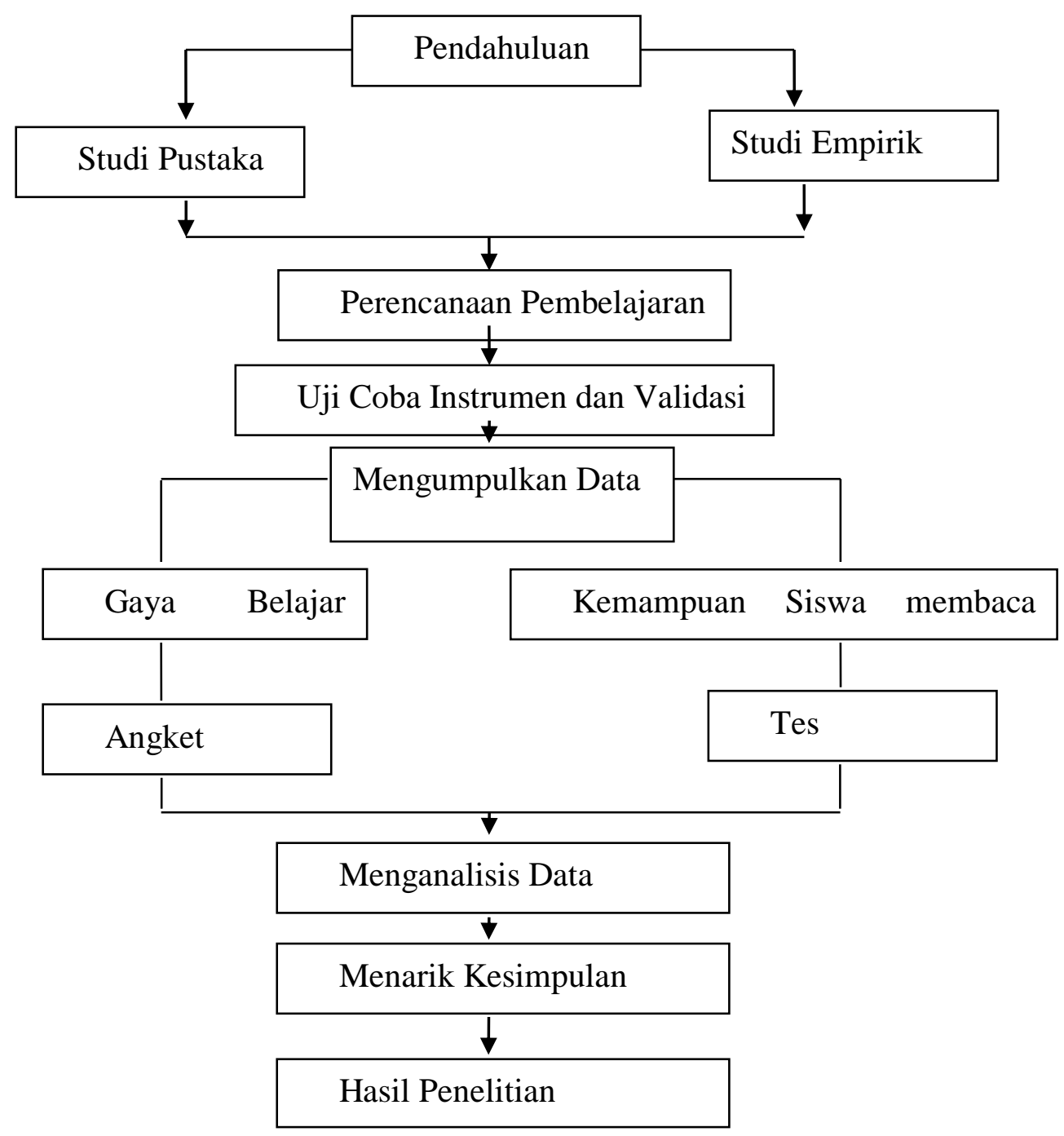

Berdasarkan gambar 1 di atas dapat dijelaskan bahwa penelitian ini diawali dengan studi pustaka dan studi empirik, yakni dengan melakukan kajian literatur dari sumber-sumber ilmiah 
dan observasi awal ke lapangan. Setelah memperoleh informasi terkait dengan data dan kondisi yang ada di lokasi tersebut kemudian peneliti memulai merancang pembelajaran. Rancangan pembelajaran ini meliputi rencana pelaksanaan pembelajaran, media pembelajaran yang dibutuhkan hingga instrumen penelitian. Selanjutnya instrumen penelitian tersebut diujicobakan ke lapangan dan/atau divalidasi oleh pakar/ahli. Setelah itu instrumen penelitian siap digunakan. Dengan menggunakan instrumen penelitian tersebut peneliti mengumpulkan data ke lapangan terkait dengan gaya belajar siswa dan kemampuan membaca intensif siswa. Data yang telah dikumpulkan kemudian dianalisis dan ditarik sebuah kesimpulan.

Menurut Arikunto (2013: 173) populasi adalah keseluruhan objek penelitian. Sedangkan sampel adalah bagian dari jumlah dan karakteristik yang dimiliki oleh populasi tersebut (Sugiyono, 2014: 118). Populasi dalam penelitian ini adalah keseluruhan siswa SD N 1 Sunyaragi Kota Cirebon tahun ajaran 2016/2017. Sementara itu, sampel dalam penelitian ini adalah siswa kelas V A yang berjumlah 23 siswa. Penentuan sampel ini menggunakan teknik sampling kelompok (sampling cluster). Menurut Hasan (2002: 90) sampling kelompok adalah bentuk sampling random yang populasinya dibagi menjadi beberapa kelompok (cluster) dengan menggunakan aturan-aturan tertentu.

Selanjutnya, teknik pengumpulan data pada penelitian ini menggunakan teknik pengumpulan data sebagai berikut: (1) angket. Angket ini ditujukan untuk mengetahui respon siswa terhadap penerapan pembelajaran menggunakan gaya belajar siswa sesudah kegiatan pembelajaran dilaksanakan. (2) tes. Tes adalah sederetan pertanyaan atau latihan atau alat lain yang digunakan untuk mengukur keterampilan, pengetahuan, intelegensi, dan kemampuan atau bakat yang dimiliki oleh individu atau kelompok (Hasan, 2009:16). Tes ini ditujukan untuk mengetahui kemampuan membaca intensif siswa pada mata pelajaran Bahasa Indonesia.

Teknik analisis data dalam penelitian ini adalah rumus prosentase angket siswa dan uji regresi sederhana. Menurut Kumaidi dan Manfaat (2014: 230) model regresi sederhana dalam bentuk hasil prediksi Y (dengan menghilangkan subkrip) apabila diketahui X dapat diungkap sebagai berikut:

$\mathrm{Y}^{\prime}=\alpha+\mathrm{bX}$

$\mathrm{Y}^{\prime}=$ skor variabel terikat yang diperkirakan dengan memakai garis regres.

$\alpha=$ intercept (titik potong garis regresi dan sumbu vertikal atau $\mathrm{Y}$ )

$\mathrm{b}=$ slope atau koefisien regresi

$\mathrm{X}=$ skor variabel bebas (independent variabel) 


\section{HASIL DAN PEMBAHASAN}

\section{A. Respon Siswa terhadap Penerapan Pembelajaran Berdasarkan Gaya Belajar Siswa}

Adapun hasil respon siswa terhadap penerapan pembelajaran berdasarkan gaya belajar siswa dapat dilihat pada diagram berikut:

Diagram 1. Hasil Respon Siswa terhadap Penerapan Gaya Belajar

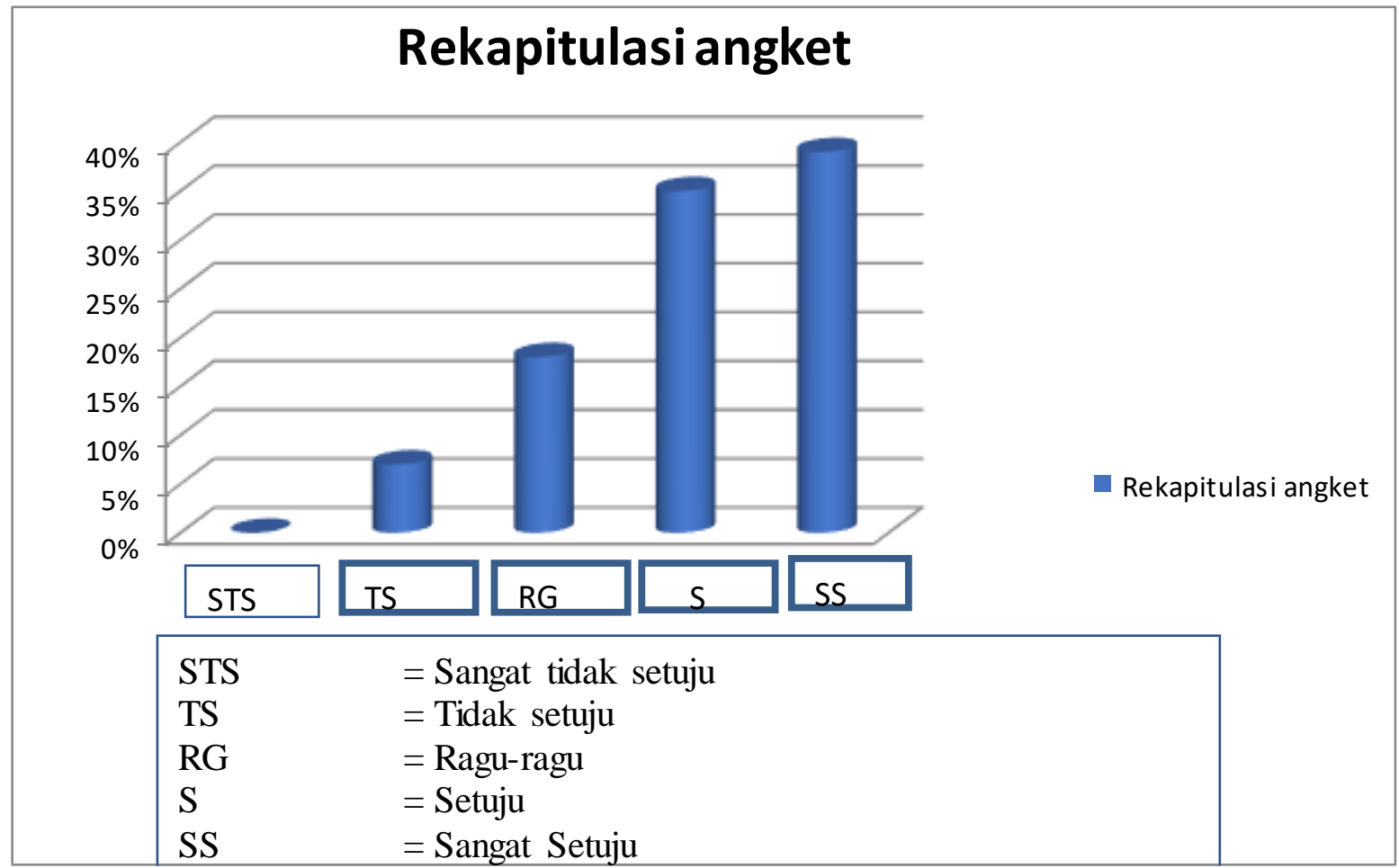

Berdasarkan diagram 1 di atas terlihat bahwa $40 \%$ siswa merespon sangat setuju terhadap penerapan pembelajaran berdasarkan gaya belajar siswa dan $34 \%$ siswa merespon setuju. Sementara itu, $18 \%$ siswa merepson ragu-ragu, $7 \%$ siswa merespon tidak setuju dan $1 \%$ merespon sangat tidak setuju. Ini berarti bahwa $74 \%$ siswa merespon baik terhadap penerapan pembelajaran berdasarkan gaya belajar siswa. Skor ini berada pada kategori tinggi karena berada pada skor $61 \%-80 \%$.

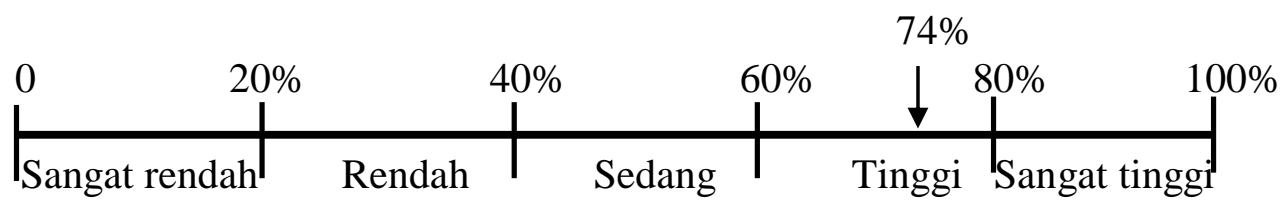

Sehingga dapat disimpulkan bahwa respon siswa terhadap penerapan pembelajaran berdasarkan gaya belajar siswa adalah tinggi, yakni sebesar $74 \%$.

\section{B. Kemampuan Membaca Intensif}

Adapun kemampuan membaca intensif siswa pada pelajaran Bahasa Indonesia di kelas V A SD Negeri Sunyaragi I Kota Cirebon adalah sebagai berikut: 
Tabel 1. Kemampuan Membaca Intensif

\begin{tabular}{|c|c|}
\hline Statistics & \\
\hline Kemampua & Membaca Intensif \\
\hline & Valid \\
\hline $\mathrm{N}$ & Missing \\
\hline Mean & 83,5652 \\
\hline Median & 87,0000 \\
\hline Mode & 87,00 \\
\hline$\overline{\text { Minim }}$ & 67,00 \\
\hline Maximur & 100,00 \\
\hline
\end{tabular}

Berdasakan tabel 1 di atas terlihat bahwa rata-rata kemampuan membaca intensif siswa sebesar 83,56, dengan nilai maximum sebesar 100 dan nilai minimum sebesar 67 . Perolehan nilai tersebut dapat disajikan ke dalam diagram berikut:

Diagram 2. Kemampuan Membaca Intinsif

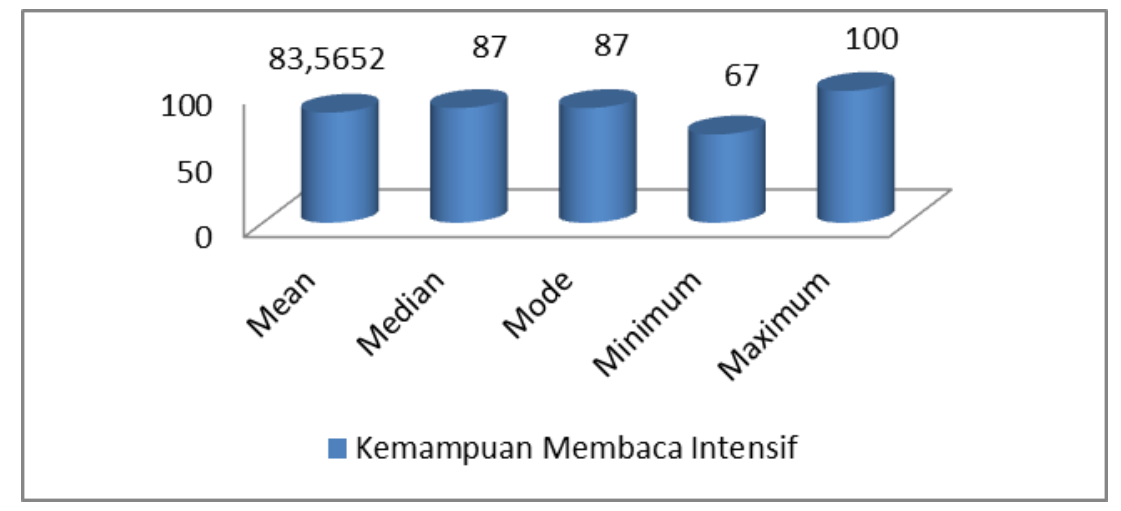

\section{Pengaruh Penerapan Pembelajaran Berdasarkan Gaya Belajar Siswa terhadap Kemampuan Membaca Intensif}

a. Uji Determinasi

Tabel 2. Hasil Uji Determinasi

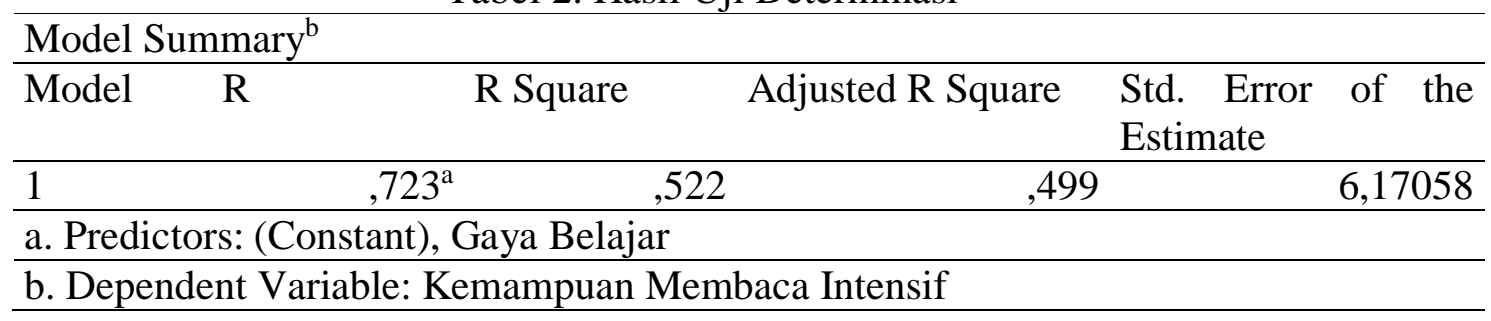

Pada Tabel 2 di atas diketahui bahwa R Square sebesar 0,522 (kuadrat dari koefisien korelasi 0,723). R Square disebut koefisien determinan yang dalam hal ini $52,2 \%$. Dari nilai tersebut dapat diartikan bahwa penerapan pembelajaran berdasarkan gaya belajar siswa pada pelajaran Bahasa Indonesia berpengaruh sebesar 52,2\% terhadap kemampuan membaca intensif siswa kelas V SDN Sunyaragi I Kota Cirebon, sedangkan sisanya dipengaruhi oleh faktor lain. 
b. Uji Regresi Sederhana

Tabel 3. Uji regresi sederhana

\begin{tabular}{|c|c|c|c|c|c|c|}
\hline \multicolumn{7}{|c|}{ Coefficients $^{\mathrm{a}}$} \\
\hline \multirow{2}{*}{\multicolumn{2}{|c|}{ Model }} & Unstandar & dized & Standardized $\mathrm{T}$ & \multirow[t]{2}{*}{ T } & \multirow[t]{2}{*}{ Sig. } \\
\hline & & $\mathrm{B}$ & Std. Error & Beta & & \\
\hline \multirow{2}{*}{1} & (Constant) & $-80,623$ & 34,293 & & $-2,351$ & ,029 \\
\hline & Gaya Belajar & 2,026 & ,423 &, 723 & 4,791 & ,000 \\
\hline
\end{tabular}

a. Dependent Variable: Kemampuan Membaca Intensif $\mathrm{Y}=\mathrm{a}+\mathrm{bX}$

Y adalah variabel dependent, dalam hal ini adalah kemampuan membaca intensif, dan $\mathrm{X}$ adalah variabel independent, dalam hal ini adalah penerapan gaya belajar. Sedangkan a dan b adalah nilai konstanta yang dicari.

Berdasarkan hasil uji regresi sederhana diketahui bahwa nilai constant-nya adalah $-80,623$ dan nilai kemampuan membaca intensif adalah 2,026. Dari keterangan tersebut kita dapat memperoleh persamaan regresi sebagai berikut:

$$
\mathrm{Y}=-80,623+2,026 \mathrm{X}
$$

Nilai konstanta dari koefficien regresi sebesar -80,623, hal ini menyatakan bahwa jika tidak ada kenaikan nilai atau skor dari variabel gaya belajar, maka variabel gaya belajar adalah sebesar -80,623. Koefficien regresi sebesar 2,026 menyatakan bahwa setiap terjadi penambahan skor variabel penerapan gaya belajar akan dapat menambah kenaikan variabel kemampuan membaca intensif.

Setelah megetahui besarnya koefisien regresi, maka perlu dilakukan pengujian hipotesis untuk megetahui apakah terdapat pengaruh atau tidak. Uji hipotesis dapat dinyatakan dengan membandingkan nilai signifikan yaitu:

Jika nilai signifikan $>0,05$ dan $\mathrm{t}_{\text {hitung }}<\mathrm{t}_{\text {tabel }}$, maka $\mathrm{H}_{0}$ diterima

Jika nilai signifikan $<0,05$ dan $\mathrm{t}_{\text {hitung }}<\mathrm{t}_{\text {tabel }}$, maka $\mathrm{H}_{0}$ ditolak

Jika $t_{\text {tabel }}$ dicari dengan $\alpha=0,05$ dan (df) $n-k-1$ atau 23-2-1 = 20, jadi $t_{\text {tabel }} 1.72472$

Hasil uji koefisien regresi pada tabel 3 di atas menunjukkan bahwa nilai signifikansinya sebesar 0,000. Karena nilai signifikansinya lebih kecil dari 0,05 dan t hitung (4.791) lebih besar dari t tabel (1.72472) maka Ho ditolak, artinya bahwa penerapan pembelajaran berdasarkan gaya belajar siswa pada pelajaran Bahasa Indonesia berpengaruh signifikan terhadap kemampuan membaca intensif siswa kelas V SDN Sunyaragi I Kota Cirebon. Jadi dapat disimpulkan bahwa penerapan pembelajaran berdasarkan gaya belajar siswa pada pelajaran Bahasa Indonesia berpengaruh sebesar 
52,2\% terhadap kemampuan membaca intensif siswa kelas V SDN Sunyaragi I Kota

Cirebon, sedangkan sisanya dipengaruhi oleh faktor lain.

Berdasarkan uraian hasil penelitian di atas menunjukkan bahwa respon siswa terhadap penerapan pembelajaran berdasarkan gaya belajar siswa pada pelajaran Bahasa Indonesia tinggi, yakni sebesar 74\%. Tingginya respon siswa tersebut menurut Widayanti (2010) karena memang gaya belajar memiliki hubungan erat terhadap proses pembelajaran dalam rangka mencapai tujuan pembelajaran. Karena pada dasarnya karakter siswa yang satu berbeda dengan siswa lainnya dan kemampuan tiap anak dalam menguasai serta memahami suatu bahan pelajaran berbeda-beda pula (Dimyati \& Mudjiono, 2002). Untuk itu perlu diterapkan pembelajaran dengan gaya belajar yang sesuai dengan karakter siswa.

Sementara itu, penerapan pembelajaran berdasarkan gaya belajar juga dapat meningkatkan kemampuan membaca intensif siswa pada pelajaran Bahasa Indonesia. Karena menurut Tubi'c \& Hamilo glu (2009) bahwa penerapan gaya belajar yang sesuai akan meningkatkan proses pembelajaran, bahkan ditegaskan pula olehnya jika ada kesesuaian antara model pembelajaran dengan gaya belajar maka akan tercipta suasana belajar produktif di dalam kelas. Oleh karenanya seorang guru perlu memahami karkateristik siswa seperti yang disampaikan oleh Dick and Carey (1996) yang menyatakan bahwa seorang guru hendaklah mampu mengenal dan mengetahui karakteristik siswa. Sebab dengan pemahaman yang baik terhadap karakteristik siswa, guru akan dapat menyesuaikan metode pembelajaran yang digunakannya yang tentunya sangat mempengaruhi keberhasilan proses belajar siswa.

Dalam penelitian yang dilakukan oleh Bire,dkk. (2014) juga mengungkapkan bahwa gaya belajar dapat mempengaruhi hasil belajar siswa. Dimana gaya belajar baik visual, audio, dan kinestetik mampu meningkatkan prestasi belajar secara signifikan. Dari hasil penelitian juga didapatkan hasil bahwa terdapat perbedaan pengaruh yang signifikan antara gaya belajar visual, audio, dan kinestetik terhadap prestasi belajar siswa. Hal ini diperkuat oleh Hasil penelitian yang dilakukan Fitriyah (2007), Kolb (2005), Hartati (2013) dan Halim (2012) yang menunjukkan bahwa penerapan gaya belajar menunjukkan pengaruh yang signifikan terhadap hasil belajar.

\section{SIMPULAN}

Berdasarkan hasil penelitian dan pembahasan dapat disimpulkan bahwa respon siswa terhadap penerapan pembelajaran berdasarkan gaya belajar siswa pada pelajaran Bahasa Indonesia di kelas V SD N Sunyaragi I Kota Cirebon tergolong pada kategori tinggi yaitu 74\% karena berada diantara 61\%-80\%. Sementara itu, kemampuan membaca intensif siswa pada pelajaran Bahasa Indonesia mengalami peningkatan yang signifikan setelah adanya penerapan pembelajaran berdasarkan gaya belajar siswa dalam proses pembelajaran yakni sebesar 83,56, 
dengan nilai maximum sebesar 100 dan nilai minimum sebesar 67. Selanjutnya, berdasarkan hasil uji koefisien regresi menunjukkan bahwa nilai signifikansinya sebesar 0,000. Karena nilai signifikansinya lebih kecil dari 0,05 dan t hitung (4.791) lebih besar dari t tabel (1.72472) maka Ho ditolak, artinya bahwa penerapan pembelajaran berdasarkan gaya belajar siswa pada pelajaran Bahasa Indonesia berpengaruh signifikan terhadap kemampuan membaca intensif siswa kelas V SDN Sunyaragi I Kota Cirebon. Besarnya pengaruh penerapan pembelajaran berdasarkan gaya belajar siswa sebesar 52,2\%, sedangkan sisanya dipengaruhi oleh faktor lain.

\section{DAFTAR PUSTAKA}

Amir, M. F. (2015). Proses Berpikir Kritis Siswa Sekolah Dasar dalam Memecahkan Masalah Berbentuk Soal Cerita Matematika Berdasarkan Gaya Belajar. Jurnal Math Educator Nusantara, 1(2), 159-170.

Arikunto, S. (2013). Prosedur Penelitian Suatu Pendekatan Praktik. Jakarta: Rineka Cipta.

Bire, A.L., dkk. (2014). Pengaruh Gaya Belajar Visual, Auditorial, dan Kinestetik Terhadap Prestasi Belajar Siswa. Jurnal Kependidikan, 44(2), 168-174.

Dick, W. and Carey, L., Carey, J.O. (2005). The Systematic Design of Instruction. New York: Logman.

Dimyati \& Mudjiono. (2002). Belajar dan Pembelajaran. Jakarta: Proyek Pembinaan Peningkatan Mutu Tenaga Kependidikan. Dikti.

Djamarah, S.B. (2010). Strategi Belajar Mengajar. Jakarta: Bineka Cipta

Fitriyah, L. A. (2007). Penerapan Model Kooperatif Tipe TAI dan Kegiatan Remidi dengan Memperhatikan Modalitas Belajar Siswa Kelas X SMA Laboratorium UM pada Pokok Bahasan Tata Nama Senyawa dan Persamaan Reaksi. Skripsi: Jurusan Kimia Universitas Negeri Malang.

Halim, A. (2012). Pengaruh Strategi Pembelajaran Dan Gaya Belajar Terhadap Hasil Belajar Fisika Siswa Smpn 2 Secanggang Kabupaten Langkat. Jurnal Tabularasa, 9(2), 141158.

Hamdu dan Agustina. (2011). Pengaruh Motivasi Belajar Siswa Terhadap Pestasi Belajar IPA di Sekolah Dasar. Jurnal Penelitian Pendidikan, 12(1), 81-86

Hartati, L. (2013). Pengaruh Gaya Belajar Dan Sikap Siswa Pada Pelajaran Matematika $\quad$ Terhadap Hasil Belajar Matematika. Jurnal Formatif, 3(3), 224-235

Hasan, I. (2002). Pokok-Pokok Materi Metodelogi Penelitian dan Aplikasinya. Bogor: Ghalia Indonesia

Hasan, I. (2009). Analisis Data Penelitian dengan Statistik. Jakarta: Bumi Aksara

Karwati, E. (2014). Manajemen Kelas. Bandung: Alfabeta

Kolb, D. A. and Kolb, A. Y. (2005). The Kolb Learning Style Inventory-Version 3.1 Technical Specifications. Experience Based Learning Systemm, Inc. Case Western Reserve University.

Kumaidi \& Manfaat, B. (2014). Pengantar Metode Statistika. Cirebon: Eduvision. 
Putri, W.A. (2013). Pengaruh Gaya Belajar Siswa Pada Mata Pelajaran Mengelola Peralatan Kantir Terhadap Hasil Belajar. Surabaya: UNESA

Sugiyono. (2014). Metode Penelitian Pendidikan. Bandung : Alfabeta

Sundayana, R. (2016). Kaitan antara Gaya Belajar, Kemandirian Belajar, dan Kemampuan Pemecahan Masalah Siswa SMP dalam Pelajaran Matematika. Jurnal Mosharafa, 5(2), 75-84.

Tubi'c, T., \& Hamilo־glu, K. (2009). Linking Learning Styles and Teaching Styles. Chapter 9: 133-143. Serbia: Faculty of Education, University of Novi Sad.

Widayanti, F. D. (2010). Pengaruh Pengelompokan Siswa Berdasarkan Gaya Belajar dan Multiple Intelligences di Kelas 18 pada Model Pembelajaran Learning Cycle terhadap Hasil Belajar Kimia Siswa Kelas XI IPA SMAN 3 Lumajang. Tesis: Pascasarjana Universitas Negeri Malang. 